\title{
EVALUASI KERUSAKAN JALAN RAYA STAGEN STA 8+100 DAN STA 9+100 DITINJAU DARI NILAI CBR TANAH DASAR DAN NILAI CESA TERHADAP TEBAL PERKERASAN JALAN EXISTING MENGACU PADA MDP 2017
}

\author{
Satriani ${ }^{1}$, Mochamad Bastomi ${ }^{2}$ \\ Prodi Teknik Sipil Politeknik Kotabaru ${ }^{1,2}$ \\ E-mail : satriani170883@gmail.com ${ }^{1}$
}

\begin{abstract}
ABSTRAK
Jalan Raya Stagen terdapat beberapa titik jalan yang berlubang dan retak yaitu pada STA $8+200$ dan 9+100 dan posisinya berada pada tikungan jalan sehingga sering kali terjadi kecelakaan. Pemerintah sering melakukan penanganan dengan menambal jalan yang berlubang tersebut, namun tidak bertahan lama.

Oleh karena itu, dilakukan evaluasi pada beberapa titik tersebut untuk mengetahui penyebab kerusakan sehingga dapat diketahui metode perbaikan yang tepat. Evaluasi meliputi pengujian CBR tanah dasar menggunakan alat DCP dan analisis terhadap lalu lintar lajur untuk mengetahui tebal perkerasan berdasarkan Manual Desain Perkerasan Revisi 2017.

Dari hasil perhitungan diperoleh nilai ESA adalah 26 juta dengan umur rencana 20 tahun dan nilai HVAG sebesar adalah 31 juta dengan umur rencana 40 tahun. Nilai CBR dan DDT STA $8+200$ adalah 0,857\%dan 1,373\% sedangkan pada STA 9+100 adalah $1,087 \%$ dan $1,823 \%$. Struktur jalan existing tidak sesuai dengan nilai CBR dan lalu lintar lajur yang terjadi berdasarkan MDP 2017. Saran perbaikan adalah dengan mebuang lapisa tanah lunak dengan lapisan penopang $1500 \mathrm{~mm}$ untuk mencapai CBR 2,5\% dan lapisan tanah $350 \mathrm{~mm}$ untuk mencapai nilai CBR 6\%. Untuk lapis perkerasan menggunakan perkerasan kaku tebal pelat beton $295 \mathrm{~mm}$ dan AC-WC $30 \mathrm{~mm}$.
\end{abstract}

Kata Kunci : Kerusakan Jalan, CBR, DDT, Lalu Lintas Lajur, MDP 2017.

\section{PENDAHULUAN}

Jalan adalah prasarana transportasi darat yang meliputi segala bagian jalan, termasuk bangunan pelengkap dan perlengkapannya yang diperuntukkan bagi lalu lintas (Permen PU No:13PRT/M/2011). Jalan juga merupakan system transportasi nasional dalam mendukung ekonomi, lingkungan, politik serta pertahanan dan keamanan. Karena banyaknya beban lalu lintas maka jalan tersebut harus kuat untuk menopang beban yang sering melintas. Beberapa factor yang mempengaruhi adalah tebal aspal dan lapis pondasi serta kepadatan tanah.

Peneliti mengambil studi kasus pada Jalan Raya Stagen pada STA $8+100$ dan 9+100 dimana terdapat titik jalan yang berlubang dan posisinya berada pada tikungan jalan sehingga sering kali terjadi kecelakaan. Pemerintah sering melakukan penanganan dengan menambal jalan yang berlubang tersebut, namun tidak bertahan lama sehingga diperlukan penanganan dan pemeliharaan yang lebih baik.

Penelitian ini dilakukan untuk mengetahui penyebab kerusakan sehingga dapat diketahui metode 
perbaikan yang tepat. Evaluasi meliputi pengujian CBR tanah dasar menggunakan alat DCP dan analisis terhadap lalu lintar lajur untuk mengetahui tebal perkerasan berdasarkan Manual Desain Perkerasan Revisi 2017.

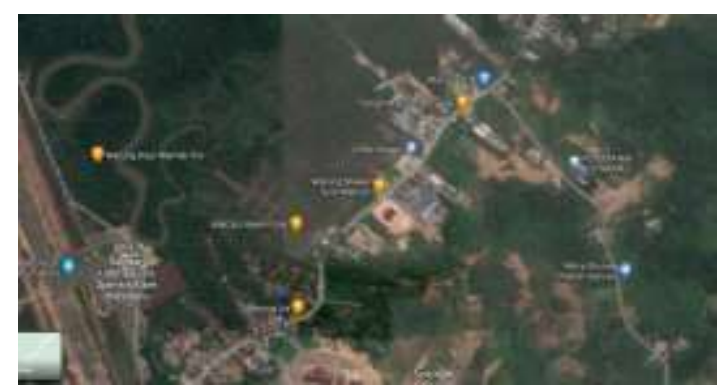

Gambar 1. Lay Out Jalan Raya Stagen STA $8+100$ dan STA 9+100

\section{TINJAUAN PUSTAKA}

\section{Kepadatan dan Daya dukung Tanah}

Beban kendaraan akan dilimpahkan ke lapis perkerasan melalui roda-roda kendaraan selanjutnya disebarkan ke lapis-lapisan di bawahnya dan akhirnya diterima oleh tanah dasar. Dengan demikian tingkat kerusakan konstruksi perkerasan selama masa pelayanan tidak saja ditentukan oleh kekuatan dari lapis perkerasan tetapi juga tanah dasar. Daya dukung tanah dasar dipengaruhi oleh jenis tanah, tingkat kepadatan, kadar air, kondisi drainase dan lain-lain. Perkerasan jalan diletakkan di atas tanah dasar, dengan demikian secara keseluruhan mutu dan kuat dukung pondasi perkerasan tak lepas dari sifat tanah dasar. Tanah lempung sangat dipengaruhi oleh kadar air yang dikandung tanah tersebut, sehingga mempengaruhi nilai California Bearing Ratio (CBR), nilai ini akan menetukan tebal lapisan perkerasan jalan tersebut. Daya dukung tanah dasar pada perencanaan perkerasan lentur dinyatakan dengan nilai CBR. (sukirman, 1999).

Untuk memperkirakan nilai CBR tanah atau bahan granular dapat menggunakan beberapa metode, namun yang cukup akurat dan paling murah sampai saat ini adalah dengan alat penetrasi konus dinamis atau dikenal dengan nama DCP. Disamping itu DCP adalah salah satu cara pengujian tanpa merusak Non Destructive Testing (NDT), yang digunakan untuk lapisan lapis pondasi batu pecah, pondasi bawah, stabilisasi dengan semen atau kapur dan tanah dasar (S. Syahruddin, 2010).

Menurut Kementerian PUPR (2017), pengujian DCP hanya dilakukan pada kondisi tanah rawa jenuh air dan kawasan alluvial kering. Nilai modulus tanah dasar yang diperoleh dari DCP harus disesuaikan dengan kondisi musim. Faktor penyesuaian minimum dapat dilihat pada Tabel 1 berikut.

Tabel 1. Faktor Penyesuaian Modulus Tanah Dasar Terhadap Kondisi Musim

Musim Faktor penyesuaian minimum nilai CBR berdasarkan pengujian DCP

\begin{tabular}{lc}
$\begin{array}{l}\text { Musim hujan } \\
\text { dan tanah } \\
\text { jenuh }\end{array}$ & 0,9 \\
\hline $\begin{array}{l}\text { Musim } \\
\text { transisi }\end{array}$ & 0,8 \\
\hline $\begin{array}{l}\text { Musim } \\
\text { Kemarau }\end{array}$ & 0,7 \\
\hline
\end{tabular}

(Kementerian PUPR, 2017)

Nilai CBR desain adalah nilai CBR hasil pengujian DCP $\mathrm{x}$ faktor penyesuaian.

Menurut Shalahuddin (2012), makin tinggi nilai CBR tanah (subgrade) maka lapisan perkerasan diatasnya akan semakin tipis dan semakin kecil nilai CBR (daya dukung tanah rendah), maka akan semakin tebal lapisan perkerasan di atasnya sesuai beban yang akan dipikulnya.

Menurut Budhianty Happy, dkk (2013), lokasi perletakkan alat DCP ditentukan sesuai dengan keperluan jalan yang akan diuji, antarlain sebagai berikut:

1. Perbaikan dengan pelebaran 
Lokasi pengujian dengan alat DCP untuk keperluan perbaikan dengan pelebaran dilaksanakan pada tepi luar perkerasan lama, posisi DCP tidak menganggu perkerasan lama. Dapat dilihat pada gambar 3 berikut.

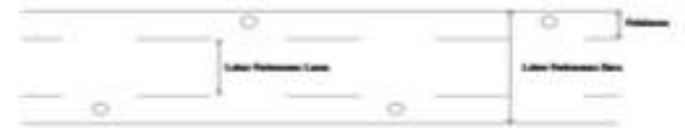

Gambar 3. Perletakan DCP untuk Perbaikan dengan Pelebaran

2. Pembangunan Jalan Baru atau Rekonstruksi

Lokasi pengujian dengan alat DCP untuk keperluan pembangunan jalan baru atau rekonstruksi dilaksanakan di jalur tengah atau center line Dapat dilihat pada gambar 4 berikut.

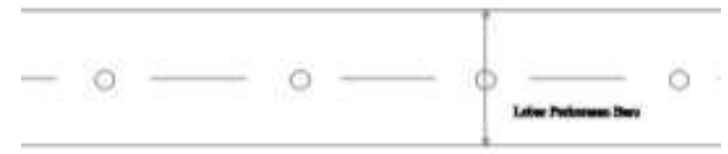

Gambar 4. Perletakan DCP pembangunan Jalan baru atau rekonstruksi

3. Overlay Jalan Aspal, akan tetapi didesain dengan Basis Data CBR

Lokasi pengujian dengan alat DCP untuk keperluan Overlay jalan aspal dilakukan pada wheel track kendaraan bermotor roda empat atau lebih. Dapat dilihat pada Gambar 5 berikut.

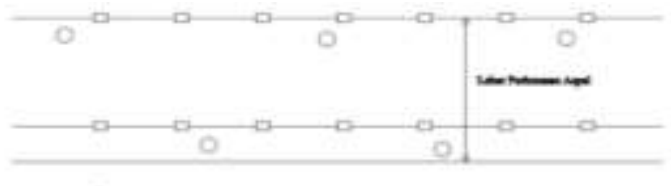

Gambar 5. Perletakan Alat DCP untuk Overlay Jalan Aspal

Metode pengujian CBR dengan alat DCP serta analisisnya mengacu pada Surat Edaran Menteri Pekerjaan Umum N0. 04/SE/M/2010 Kementerian Pekerjaan Umum (2010).

\section{Analisa Volume Lalu Lintas}

Parameter yang penting dalam analisis struktur perkerasan adalah data lalu lintas yang diperlukan untuk menghitung beban lalu lintas rencana yang dipikul oleh perkerasan selama umur rencana. Beban dihitung dari volume lalu lintas pada tahun survei yang selanjutnya diproyeksikan ke depan sepanjang umur rencana. Volume tahun pertama adalah volume lalu lintas sepanjang tahun pertama setelah perkerasan diperkirakan selesai dibangun atau direhabilitasi. Analisis Volume lalu lintas didasarkan pada survey yang diperoleh dari survei lalu lintas, dengan durasi minimal 7 x 24 jam. Survei dapat dilakukan secara manual mengacu pada pedoman survey Pencacahan Lalu Lintas (Pd T-19-2004-B) atau menggunakan peralatan dengan pendekatan yang sama. Dalam analisis lalu lintas, penentuan volume lalu lintas pada jam sibuk dan lalu lintas harian rata - rata tahunan (LHRT) mengacu pada Manual Kapasitas Jalan Indonesia (MKJI).

Faktor pertumbuhan lalu lintas berdasarkan data-data pertumbuhan series (historical growth data) atau formulasi korelasi dengan faktor pertumbuhan lain yang berlaku. Jika tidak tersedia data maka Tabel 2 dapat digunakan (2015 - 2035).

Tabel 2. Faktor laju Pertumbuhan Lalu

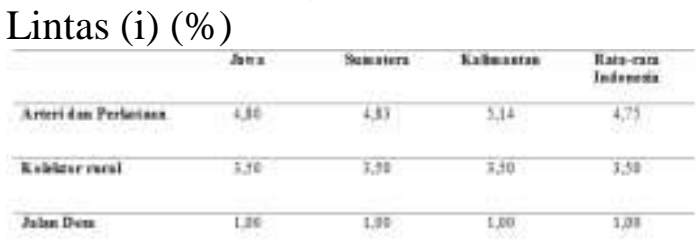

(Kementerian PUPR, 2017)

Pertumbuhan lalu lintas selama unsur rencana dihitung dengan faktor pertumbuhan kumulatif (Cumulative Growth Factor):

$$
R=\frac{\left((1+0,01 i)^{\wedge} U R\right)-1}{0,01 i}
$$


Dengan :

$\mathrm{R}=$ faktor pengali pertumbuhan lalu lintas kumulatif

$\mathrm{i}=$ laju pertumbuhan lalu lintas tahunan (\%)

$\mathrm{UR}=$ umur rencana (tahun)

Apabila diperkirakan akan terjadi perbedaan laju pertumbuhan tahunan sepanjang total umur rencana (UR), dengan $\mathrm{i}_{1} \%$ selama periode awal (UR1 tahun) dan $\mathrm{i}_{2} \%$ selama sisa periode berikutnya (UR - UR1), faktor pengali pertumbuhan lalu lintas kumulatif dapat dihitung dari formula berikut:

$$
\begin{aligned}
& \mathrm{R}=\frac{\left(\left(1+0,01 i_{1}\right)^{U R 1}\right)-1}{0,01 i_{1}}+\left(1+0,01 \mathrm{i}_{1}\right)^{(\mathrm{UR} 1-} \\
& { }^{1)}\left(1+0,01 \mathrm{i}_{2}\right)\left\{\frac{\left(1+0,01 i_{2}\right)^{(U R-U R 1)}-1}{0,01 i_{2}}\right\}
\end{aligned}
$$

Dengan:

$\mathrm{R}=$ faktor pengali pertumbuhan lalu lintas kumulatif

$\mathrm{i}_{1}=$ laju pertumbuhan lalu lintas periode $1(\%)$

$\mathrm{i}_{2}=$ laju pertumbuhan tahunan lalu lintas periode $2(\%)$

UR = total umur rencana (tahun)

UR1= umur rencana periode 1 (tahun)

Apabila kapasitas lalu lintas diperkirakan tercapai pada tahun ke (Q) dari umur rencana (UR), faktor pengali pertumbuhan lalu lintas kumulatif sebagai berikut:

$R=\frac{(1+0,01 i)^{Q-1}}{0,01 i}(\mathrm{UR}-\mathrm{Q})(1+0,01 \mathrm{i})^{\mathrm{Q}-1}$

Lajur rencana adalah salah satu lajur lalu lintas dari suatu ruas jalan yang menampung lalu lintas kendaraan niaga (truk dan bus) paling besar. Beban lalu lintas pada lajur rencana dinyatakan dalam kumulatif beban gandar standar (ESA) dengan memperhitungkan faktor distribusi arah (DD) dan faktor distribusi lajur kendaraan niaga (DL). Untuk jalan dua arah, faktor distribusi arah (DD) umumnya diambil 0,50 kecuali pada lokasi-lokasi yang jumlah kendaraan niaga cenderung lebih tinggi pada satu arah tertentu. Beban sumbu standar kumulatif atau Cumulative Equivalent Single Axle Load (CESAL) merupakan jumlah kumulatif beban sumbu lalu lintas desain pada lajur desain selama umur rencana, yang ditentukan sebagai berikut: Menggunakan VDF masing-masing kendaraan niaga.

$\mathrm{ESA}_{\mathrm{TH}-1}=\left(\sum \mathrm{LHR}_{\mathrm{jk}} \times \mathrm{VDF}_{\mathrm{jk}}\right) \times 365 \times$ $\mathrm{DD} \times \mathrm{DL} \times \mathrm{R}$

Dengan :

$\mathrm{ESA}_{\mathrm{TH}-1}$ : kumulatif lintasan sumbu standar ekivalen (equivalent standard axle) pada tahun pertama.

$\mathrm{LHR}_{\mathrm{jk}}$ : lintas harian rata-rata tiap jenis kendaraaan niaga (satuan kendaraan per hari)

$\mathrm{VDF}_{\mathrm{JK}}$ : Faktor Ekuivalen Beban (Vehicle Damage Factor) tiap jenis kendaraan niaga

DD : Faktor Distribusi arah.

DL : Faktor Distribusi Lajur

CESAL : Komulatif Beban Sumbu Standar ekivalen selama umur rencana.

R : Faktor pengali pertumbuhan lalu lintas kumulatif .

\section{Desain Perkerasan}

Menurut Kementerian PUPR (2017), desain tebal perkerasan didasarkan pada nilai ESA pangkat 4 dan pangkat 5, tergantung pada model kerusakan dan pendekatan desain yang digunakan.

1. Pangkat 4 digunakan pada desain perkerasan lentur berdasasrkan Pedoman Perencanaan Tebal Perkerasan Lentur Pt T-01-2002-B atau metode AASHTO 1993. Pangkat 4 digunakan untuk bagian desain pelaburan tipis (seperti Burtu atau Burda), perkerasan tanpa penutup dan perencanaan overlay berdasarkan grafik lendutan untuk kriteria alur (rutting). 
2. Pangkat 5 digunakan untuk desai perkerasan lentur termasuk perencanaan tebal over lay berdasarkan grafik garis lengkung lendutan untuk kriteria retak lelah.

3. Desain perkerasan kaku menggunakan jumlah kelompok sumbu kendaraan berat dan bukan nilai ESA sebagai satuan lalu lintas untuk perkerasan beton.

\section{METODE PENELITIAN}

\section{Lokasi Penelitian}

Penelitian dilakukan pada Jalan Raya Stagen KM 8,2 dan KM 9,1. Pemilihan lokasi ini disebabkan penulis ingin menganalisa kerusakan jalan yang ada sehingga dapat ditentukan metode perbaikan yang tepat untuk jalan tersebut.

\section{Metode Pengujian CBR Menggunakan} Alat DCP

Adapun Prosedur pengujian adalah sebagai berikut:

1. Gali permukaan jalan selebar $60 \times 60$ $\mathrm{cm}$, sampai diperoleh lapisan tanah dasar sekaligus untuk megetahui tebal perkerasan sebelumnya.

2. Letakkan alat DCP pada titik uji diatas lapisan yang akan diuji.

3. Pegang alat yang sudah terpasang pada posisi tegak lurus di atas dasar rata yang dan stabil, kemudian catat pembacaan awal pada mistar pengukur kedalaman.

4. Mencatat jumlah tumbukan.

5. Hentikan pengujian apabila kecepatan penetrasi kursng dari $1 \mathrm{~mm} / 3$ tumbukan.

6. Pengujian per titik, dilakukan minimum (dua kali) dengan jarak 20 cm titik uji satu ke titik uji lainnya.

7. Tutup kembali lubang uji setelah pengujian.

\section{Metode Pengambilan Data Lalu Lintas}

Prosedur pengambilan data lalu lintas adalah dengan melakukan pengamatan lalu lintas pada Jalan Raya Stagen selama
$7 \times 24$ jam menggunakan rekaman CCTV MM Rika yang berada pada Jalan Raya KM. 8,3.

\section{HASIL PENELITIAN}

\section{Tebal Lapis Perkerasan Existing}

Kondisi badan jalan pada titik yang ditinjau sudah rusak berat dan berlubang. Untuk mengetahui lapisan perkerasan jalan existing maka dilakukan penggalian pada badan jalan yang masih baik di sekitar badan jalan yang rusak dengan ukuran $60 \times 60 \mathrm{~cm}$ diperoleh ketebalan lapis pondasi adalah $40 \mathrm{~cm}, \mathrm{AC}-\mathrm{BC}$ adalah $60 \mathrm{~cm}$ dan AC-WC adalah $40 \mathrm{~cm}$.

\section{Perhitungan Nilai CBR}

Pengujian CBR menggunakan alat DCP dengan konus $30^{\circ}$. Kondisi musim saat pengambilan sampel adalah saat musim hujan. Grafik pengujian DCP pada STA $8+200$ dapat dilihat pada Gambar 6 berikut.

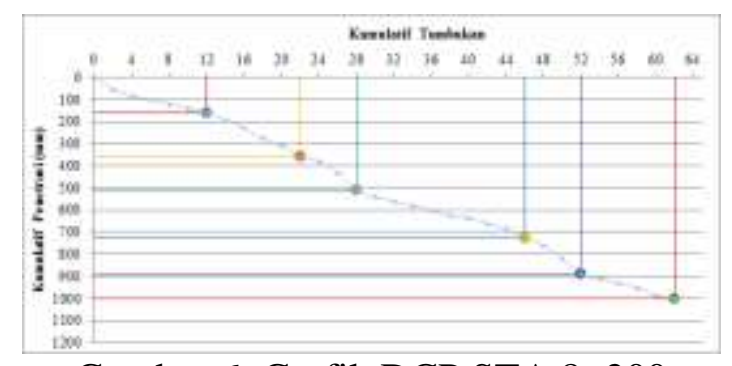

Gambar 6. Grafik DCP STA 8+200

Dari Gambar 6 di atas, selanjutnya dihitung nilai CBR lapangan sesuai dengan kondisi tanah saat itu menggunakan persamaan berikut selanjutnya hasil analisis dapat dilihat pada Tabel 3 berikut.

DCP = Banyaknya Penetrasi/Banyaknya Tumbukan

$\mathrm{CBR}=1,352-1,125 \log 10(\mathrm{DCP})$

$\mathrm{CBR}$ rata-rata $=$ Jumlah $\mathrm{CBR}$ setiap segmen / Banyaknya Segmen

$\mathrm{DDT}=1,6649+4,3592 \log (\mathrm{CBR})$ 
Tabel 3. Pengolahan Data DCP STA

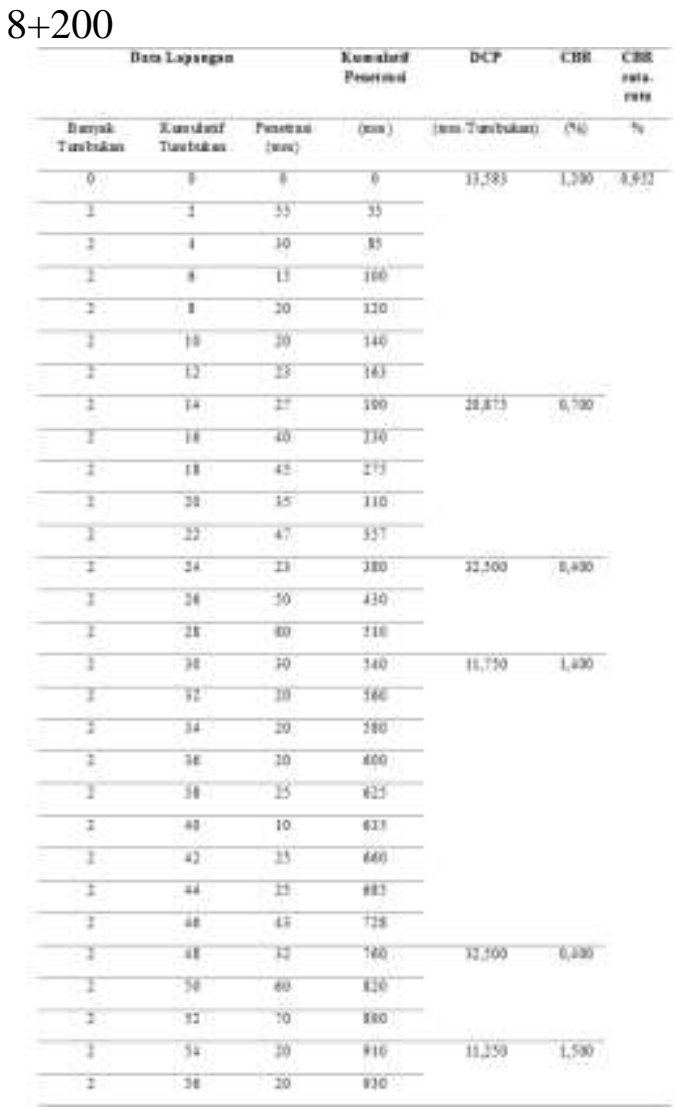

(Hasil Pengolahan Data, 2021)

Dari data di atas, diperoleh bahwa nilai CBR rata-rata pada Jalan Raya Stagen STA $8+200$ adalah 0,952\%, karena pengukuran pada musim hujan, maka factor penyesuaian adalah 0,9 sehingga nilai CBR STA $8+200$ adalah $0,857 \%$ dengan DDT $1,373 \%$.

Dengan metode analisis yang sama diperoleh untuk STA 9+100 nilai CBR adalah $1,087 \%$ dan DDT $1,823 \%$.

Adapun data lapangan untuk STA 9+100 dengan alat DCP yang disajikan dalam Gambar 7 berikut.

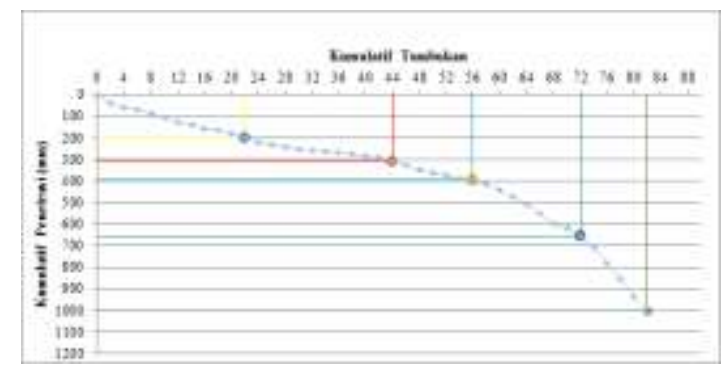

Gambar 7. Grafik DCP STA 9+100
Dari data CBR tanah dasar pada kedua titik analisis tersebut diketahui bahwa tanah tersebut termasuk dalam kategori tanah lunak dengan daya dukung tanah sangat rendah, hal ini menjadi pemicu kerusakan badan jalan pada titik tersebut. Perlu perbaikan tanah dasar untuk mencapai CBR desain $\geq 6 \%$, baik dengan pemadatan atau stabilisasi sampai dengan mencapai nilai lebih dari 2,5\% atau lapisan tanah tersebut dibuang dan diganti dengan lapisan penopang. Tebal lapis penopang disesuaikan dengan lalu lintas lajur desain.

\section{Perhitungan Nilai CESA}

Untuk data pengamatan dilapangan penulis menggunakan rekaman video CCTV DARI minimarket Rika. Penulis mengambil video rekaman CCTV dengan durasi selama tujuh hari dari tanggal 29 Juni 2020 sampai tanggal 05 Juli 2020. Dalam satu hari pengamatan penulis membagi menjadi empat periode yaitu enam jam pada satu periode pengamatan. Dalam pengamatan penulis membagi jenis kendaraan berdasarkan jumlah sumbu. Kemudian untuk Faktor distribusi Arah berdasarkan jalan raya Stagen memiliki 2 Arah jadi penulis membagi pengamatan pada setiap periode menjadi 2 bagian yaitu Arah kiri dari arah kota menuju pedesaan dan arah kanan dari arah pedesaan ke kota.

Jenis Kendaraan yang melintas selama tujuh hari pengamatan pada Jalan Raya Stagen ada 5 jenis yaitu 5B,6A,6B,7A1 dan 7A2, dapat dilihat pada Tabel 4 berikut.

Tabel 4. Rekapitulasi Hasil Pengamatan LHR dari CCTV

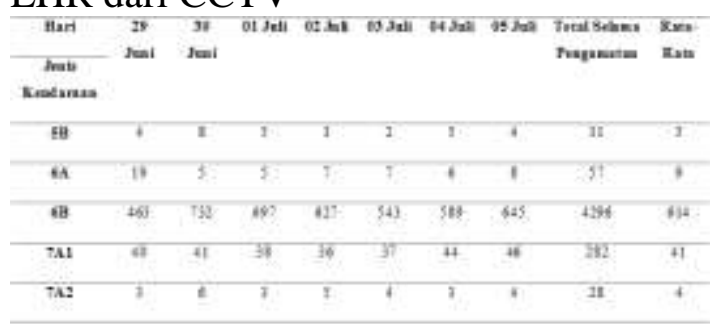

(Hasil Pengolahan Data, 2021) 
Faktor laju pertumbuhan lalu lintas $(i)$ adalah 5,14\% sesuai dengan Table 4.1 MDP 2017. Maka kumulatif beban (ESA5) adalah:

1. Perhitungan LHR Tahun 2022

Perhitungan LHR pada Tahun 2022 ini penulis mengambil sampel kendaraan jenis 5B, Perhitungan sebagai berikut.

$$
\begin{aligned}
\mathrm{LHR}_{2022} & =\mathrm{LHR}_{2020} \times(1+\mathrm{i})^{3} \\
& =5 \times(1+0,0514)^{3} \\
& =6
\end{aligned}
$$

2. Perhitungan ESA 2022

$$
\begin{aligned}
& \mathrm{ESA}_{2022}=\mathrm{LHR}_{2020} \times \text { VDF5 Faktual } \mathrm{x} \\
& 365 \times \mathrm{DD} \times \mathrm{DL} \times \mathrm{R}_{(2020-2022)} \\
& =5 \times 1 \times 365 \times 0,5 \times 1 \times \\
& 3,1568 \\
& =2,88 \times 10^{3}
\end{aligned}
$$

3. Perhitungan CESAL

$$
\begin{aligned}
\text { CESAL }= & \text { Jumlah ESA Setiap jenis } \\
& \text { Kendaraan } \\
= & \text { ESA }_{5 \mathrm{~B}}+\mathrm{ESA}_{6 \mathrm{~A}}+\mathrm{ESA}_{6 \mathrm{~B}} \\
& +\mathrm{ESA}_{7 \mathrm{~A} 1}+\mathrm{ESA}_{7 \mathrm{~A} 2} \\
= & 2,65 \times 10^{7}
\end{aligned}
$$

Beban standar kumulatif atau Cumulative Equivalent Single Axle Load (CESAL) merupakan jumlah beban sumbu lalu lintas desain pada lajur desain selama umur rencana, Adapun Tabel Perhitungan ESA diatas untuk jenis kendaraan yang lain dapat di lihat pada table 5 berikut.

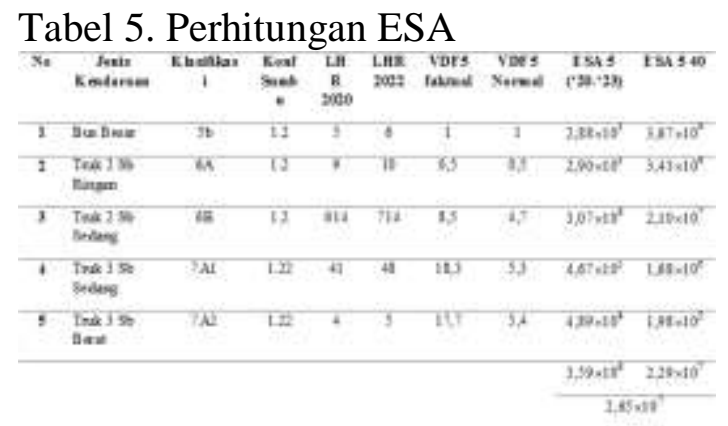

(Hasil Pengolahan Data, 2021)

Kelompok Sumbu Kendaraan Berat
Beban ini digunakan untuk perkerasan kaku dimana untuk umur rencana perkerasan ini yaitu 40 tahun. Perkerasan kaku tidak menggunakan nilai ESA tetapi menggunakan Heavy Vehicle Axle Group (HVAG). Adapun Hasil Perhitungan pada tabel 6 .

1. Perhitungan Kelompok Sumbu

Perhitungan Kelompok Sumbu pada Tahun 2020 ini penulis mengambil sampel kendaraan jenis 5B, Perhitungan sebagai berikut.

Kelompok Sumbu ${ }_{2020}=\mathrm{LHR}_{2020} \mathrm{x}$ Jumlah Kelompok Sumbu

$$
\begin{aligned}
& =5 \times 2 \\
& =10
\end{aligned}
$$

2. Perhitungan Faktor Pertumbuhan Lalu Lintas

$R_{2020-3040}=\quad \begin{array}{cc}(1+\mathrm{i})^{\mathrm{U} U \mathrm{R}}-1= & (1+0,0514)^{40}-1 \\ \mathrm{I} & 0,0514\end{array}$ $=125,007$

3. Pehitungan Jumlah Kelompok Sumbu 2020-2040

Jumlah Kelompok Sumbu $2020-2040$ $=$ Kelompok Sumbu 2020 x 365 x DD x DL x R $\mathrm{R}_{(2020-2040)}$

$=10 \times 365 \times 0,5 \times 1 \times 125,007$

$=2,28 \times 10^{5}$

4. Perhitungan Kumulatif Kelompok Sumbu 2020-2040

Kumulatif Kelompok Sumbu 2020$2040=5 \mathrm{~B}+6 \mathrm{~A}+6 \mathrm{~B}+7 \mathrm{~A} 1+7 \mathrm{~A} 2$ $=3,15 \times 10^{7}$

Tabel 6. Perhitungan HVAG untuk Perkerasan Kaku

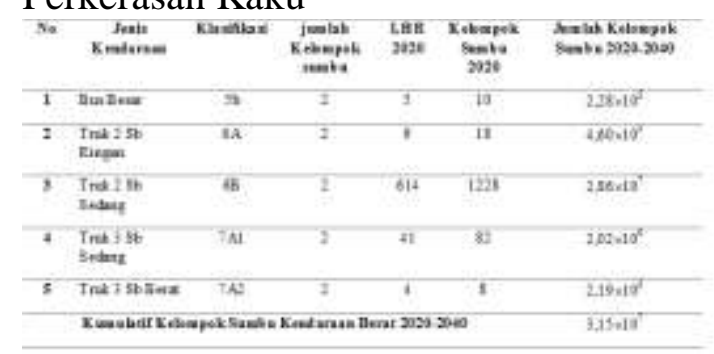

(Hasil Pengolahan Data, 2021)

\section{Analisis Tebal Lapis Perkerasan}

Untuk analisis tebal tersebut penulis melakukan dengan jenis perkerasan dan jenis aspal yang sama pada jenis kontruksi yang sudah ada dilapangan. 
Untuk tebal perkerasan lentur penulis menggunakan bagan desain 3B dengan ESA 26,5 juta dan perkerasan kaku menggunakan bagan desain 4 dengan HVAG 31,5 juta. Maka jenis perkerasan yang disarankan adalah Perkerasan Aspal Beton dengan Cement Treated Base (CTB) atau dengan Perkerasan Kaku. Discounted lifecycle cost perkerasan kaku umumnya lebih rendah untuk jalan dengan beban lalu lintas lebih dari 30 juta ESA4.

Kemudian untuk tebal perbaikan tanah dasar dengan menggunakan bagan desain 2 didapatkan tebal dengan lapisan berbutir $1500 \mathrm{~mm}$ untuk mencapai CBR 2,5\% dan lapisan tanah $350 \mathrm{~mm}$ untuk mencapai nilai CBR 6\%. Dimana nilai $\mathrm{CBR} \geq 6 \%$ adalah nilai $\mathrm{CBR}$ tanah yang harus dicapai agar bisa dilanjutkan ke perkerasan selanjutnya.

Kemudian pada STA ini jenis perkerasan yang digunakan dilapangan adalah perkerasan lentur dengan jenis aspal AC. Untuk perhitungan berdasarkan MDP Revisi 2017 menggunakan bagan desain 3B didapatkan total semua lapisan setebal $2410 \mathrm{~mm}$ (ditambah dengan tebal perbaikan tanah dasar), maka agar lapisan tidak terlalu tinggi lebih baiknya menggunakan alternatif bagan desain 4 (perkerasan kaku) dengan mengganti lapisan dibawah aspal menggunakan perkerasan kaku.

Adapun tebal perkerasan dengan analisis menggunakan metode MDP Revisi 2017 dapat dilihat pada tabel 7 berikut.

Tabel 7. Tebal Perkerasan Kaku Metode MDP Revisi 2017

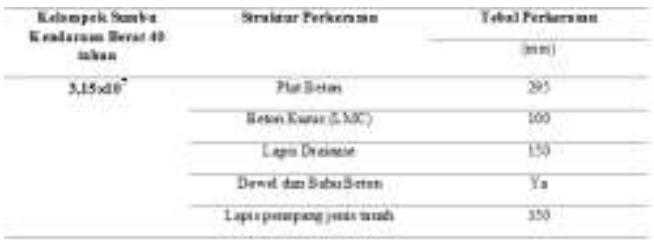

(Perkerasan Kaku, 2017)

\section{KESIMPULAN}

1. Nilai CBR pada Jalan Raya Stagen STA $8+200$ adalah $0,857 \%$ dengan DDT $1,373 \%$ dan untuk STA 9+100 nilai CBR adalah $1,087 \%$ dan DDT $1,823 \%$.

2. Nila ESA 26,5 juta dan HVAG 31,5 juta.

3. Perlu perbaikan tanah dasar dengan mengganti lapisan tanah lunak dengan lapis penopang setebal 1500 mm untuk mencapai CBR 2,5\% dan lapisan tanah $350 \mathrm{~mm}$ untuk mencapai nilai CBR 6\%.

Untuk lapis perkerasan menggunakan perkerasan kaku tebal pelat beton $295 \mathrm{~mm}$ dan AC-WC 30 $\mathrm{mm}$.

\section{DAFTAR PUSTAKA}

Adiwijaya, Tangke Datu Irka, Khairil, 2018, Penerapan Slag Baja Sebagai Pengganti Agregat Pada Karakteristik Self Compacting Concrete, Prosiding Seminar Hasil Penelitian (SNP2M) 2018 (pp.166-171), Politeknik Negeri Ujung Pandang, Makassar.

Arief Purnomo, Febry., 2012, Tinjauan Kuat Tekan Dan Modulus Elastisitas

Beton Dengan Variasi Kadar Slag dan Aktivator Sebagai Pengganti Sebagian Semen, Universitas Sebelas Maret, Surakarta.

Hanif, 2012, Penggunaan Steel Slag dengan Variasi FAS terhadap Kuat Tekan Beton. Jurnal Ilmu Pengetahuan dan Teknologi Terapan, REINTEK. Vol.7, No.2.Tahun 2012. ISSN 19075030. Politeknik Negeri Lhokseumawe.

Masykur, M., \& Kurniawan, S. (2017). Analisa Pengujian Dynamic Cone Penetrometer (DCP) Untuk Daya Dukung Tanah Pada Perkerasan 
Jalan Overlay (Studi Kasus: Ruas Jalan Metro-Tanjungkari STA $7+000$ s/d STA 8+ 000).

TAPAK (Teknologi Aplikasi Konstruksi): Jurnal Program Studi Teknik Sipil, 7(1), 52-63.

Moenir Misbachul, Irnaning Handayani Novarina, 2012, Recycling Limbah Padat Industri Peleburan Besi (Iron Slag) Sebagai Bahan Campuran Industri Beton yang Berwawasan Lingkungan. Jurnal Riset Teknologi Pencegahan Pencemaran Industri. ISSN 20870965. Balai Besar Teknologi Pencegahan Pencemaran Industri, Semarang.

Tangke Datu, Irka., 2013, Karakteristik Mekanis Beton Mutu Tinggi Polypropylene Fiber yang Menggunakan Limbah Slag Baja Sebagai Agregat Kasar, Seminar Nasional III Teknik Sipil 2013, Universitas Muhammadiyah Surakarta.

Tangke Datu, Irka., 2019, Evaluasi Pemanfaatan Limbah Slag Baja Sebagai Agregat Halus Pada Produksi Beton Mutu Tinggi, Prosiding Seminar Nasional Penelitian \& Pengabdian Kepada Masyarakat 2019 (pp.119-123), 978-602-60766-7-0. 